\title{
Critical success factors of public-private partnership from 2000 to 2019: A literature review
}

\author{
Lydia Natalia*; Nanny Dewi Tanzil; Prima Yusi Sari \\ Department of Accounting, Faculty of Economics and Business, Universitas Padjadjaran, \\ Indonesia
}

*To whom correspondence should be addressed. Email: natalia.lydia25@gmail.com

\begin{tabular}{|l|l|l|l|l|}
\hline DOI: & Received: & Revised: & Accepted: & Published: \\
10.22437/ppd.v8i6.10742 & 21.10 .2020 & 01.01 .2021 & 10.01 .2021 & 01.02 .2021 \\
\hline
\end{tabular}

\begin{abstract}
Public-Private Partnership (PPP) is one of the schemes that have inspired many countries in infrastructure development. One of the most discussed PPP topics by researchers is the concept of Critical Success Factors (CSF). Therefore, this study examines CSF publications for PPP projects from selected journal sites from 2000-2019. The results showed that research on CSF in PPP began to increase in 2012. The most identified CSFs were appropriate risk allocation and sharing, competitive and transparent procurement processes, favorable and efficient legal frameworks, commitment and responsibility of the public and private sectors, and a robust and reliable private consortium. Furthermore, it was also found that most countries that were the objects of research on PPP CSF were China, followed by Hong Kong and Australia. The results also show that the dominant research focuses on multi-sector types of infrastructure where CSF can be applied to all infrastructure sectors. The findings obtained in this study can provide an overview of CSFs for projects with PPP schemes in the future. Besides, the identified CSFs can be applied to any PPP infrastructure sector. They can assist stakeholders in increasing the likelihood of PPP project success and can be adopted for further research.
\end{abstract}

Keywords: Critical Success Factors, Public-Private Partnership, Infrastructure

JEL Classification: G32, M21, M41

\section{INTRODUCTION}

Governments worldwide are increasingly adopting Public-Private Partnership (PPP) policies to terminate large infrastructure gaps, and there is growing interest in adopting these policies in both developed and developing countries. Many governments around the world are now trying to use private sector expertise and resources. It to reduce infrastructure shortages, especially those related to public services.

PPPs are an increasingly valuable tool for public infrastructure development and the provision of public services. PPP has drawn many researchers' interest since this type of partnership was introduced to the construction sector. By identifying the most critical features of the project, several researchers have sought to enhance PPP projects' functionality to find valuable strategies for better implementation (Ke et al., 2009).

Over the years, research on PPP has been carried out in various aspects following the growing popularity of PPP in the world's eyes. These various aspects include risk management and risk allocation (Li et al., 2001; Grimsey and Lewis, 2002; Hwang et al., 2013), financial feasibility studies (Zhang, 2005), and Value for Money (Cheung et al., 
2009; Siemiatycki and Farooqi, 2012).

From that period, discussion of Critical Success Factors (CSF) has also gained much more focus, following research trends on PPP from 1998 to 2008 conducted by Ke et al. (2009) and research conducted by Tang et al. (2010). CSF is one aspect of PPP that is of particular concern to researchers.

With the growth of research on CSF in PPP projects, it is considered necessary to conduct a literature review to (1) observe the development of CSF research on PPP projects from 2000 to 2019, (2) identify countries that are the subject of CSF research, (3) identify the infrastructure sectors that have been explored in previous CSF studies, and (4) identify the dominant CSF from the results of previous research.

\section{METHODS}

A systematic analysis of journal publications is necessary to thoroughly review and analyze the results from previous research on a specific subject or field of study. In this regard, three stages needed consists of (1) selection of target journals, (2) selecting target papers, and (3) examining target papers.

\section{Selection of target journals}

The academic journals published articles with CSF research were identified first. The publications used are only publications with the Q1 category whose validity was obtained through the Scimagojr.com website.

The articles used in this study were all national and international scientific articles published on these databases: ScienceDirect, Emerald Insight, AsceLibrary, Sage Journal, Directory of Access Journal, Springer, and Wiley Online Library.

The search keywords included "critical success factors", "critical factors", and "success factors", which are limited to the PPP area by using the keyword "public-private partnership". Papers with these specific terms in the title, abstract, or keywords were considered to have met the study requirements. Moreover, the search restricted to the subject areas of "social sciences", "business", "accounting", "management", "engineering", "environment", "econometrics, finance and economics", "energy", "environmental science" and "decision sciences" with the document type of "article or review".

Based on the research results, academic journals that publish articles about PPP CSF and within the Q1 category obtained as follows: Engineering, Construction and Architectural Management (ECAM), Journal of Construction Engineering and Management (JCEM), Facilities, Cities, Global Journal of Flexible Systems Management, Habitat International, International Journal of Project Management (IJPM), International Journal of Public Sector Management (IJPSM), Journal of Management in Engineering (JME), Maritime Economics and Logistics, Project Management Journal, Public Administration Review, and Transport Policy. Henceforth these journals were selected as the target academic journals for further analysis.

\section{Selecting target papers}

From 7 search engines obtained 2,448 articles, then checked briefly by reading the abstract and its contents to filter out unrelated papers. Based on 13 journals that were selected, 28 articles are about PPP CSF within the Q1 category.

Regardless of the extensive search for publications on the PPP CSF, the number of articles extracted from journals selected may not be complete and does not include all publications in the field of PPP under study. Therefore, it must be emphasized that the analysis is based solely on data obtained using the specific sampling approach adopted in this study. Moreover, this study not intended to examine the entire article on CSF PPP. 
However, it is expected to provide an overview of CSF PPP research trends and the most frequently cited success factors for future implementation.

\section{Examining target papers}

The articles obtained are then analyzed by reading the entire article content includes the research objectives, framework, methods, results, and conclusions. The results presented into four categories: (1) the development trend of PPP CSF research in the 2000-2019 period, (2) the most researched countries as research objects, (3) the infrastructure sector, which was the most researched, and (4) identification of findings most CSF in research during 2000-2019.

\section{RESULTS AND DISCUSSION}

\section{Publication statistics for critical success factors on PPP Projects}

Figure 1 presents the number of publications per year from 2000 to 2019. The numbers presented are the results of searching for articles through seven portals that have been selected for use in this study. Figure 1 shows that the total published articles found according to the predetermined criteria are 28 articles from 2000 to 2019.

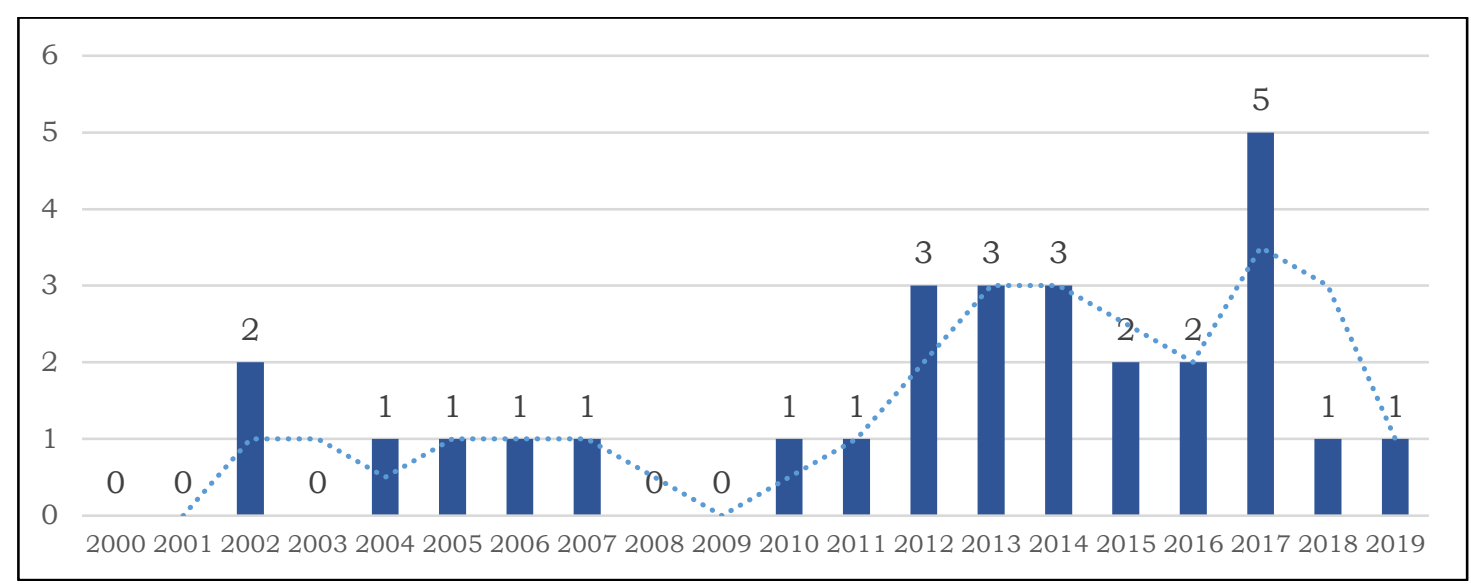

Figure 1. Publication statistics for critical success factors on PPP Projects in 2000-2019

There were 8 CSF articles for PPP from 2000 to 2011. It indicates that even though PPP had developed sufficiently in various countries, only a few researchers made CSF for PPP as their study's focus. However, there was an increase from 2012 to 2019 when 20 articles were obtained. It illustrates that PPP is a reasonably significant means of realizing infrastructure development accompanied by public services. Simultaneously, researchers are increasingly involved in reviewing infrastructure development practices with the PPP scheme and developing various methods to better implement PPP. Findings in previous research indicate that CSF is one of the topics of interest to researchers (Ke et al., 2009).

\section{CSF research object countries in PPP Projects}

Not all articles use only one country as the object of research. Several studies observed several countries within a study to compare PPP in these countries (Chou \& Pramudawardhani, 2015; Zhang et al., 2012; Osei-Kyei \& Chan, 2017a; Abdel Aziz, 2007). Several studies also conceptualize CSF research at the international level to apply to any country (Osei-Kyei \& Chan, 2017b; Zhang, 2005; Kumaraswamy \& Morris, 2002).

Figure 2 shows that the discussion on 35 countries is contained in 28 research articles. By setting aside the international concept, China appears to be the region widely studied as the research objects ( 5 publications), followed by Hong Kong and Australia with three publications. 


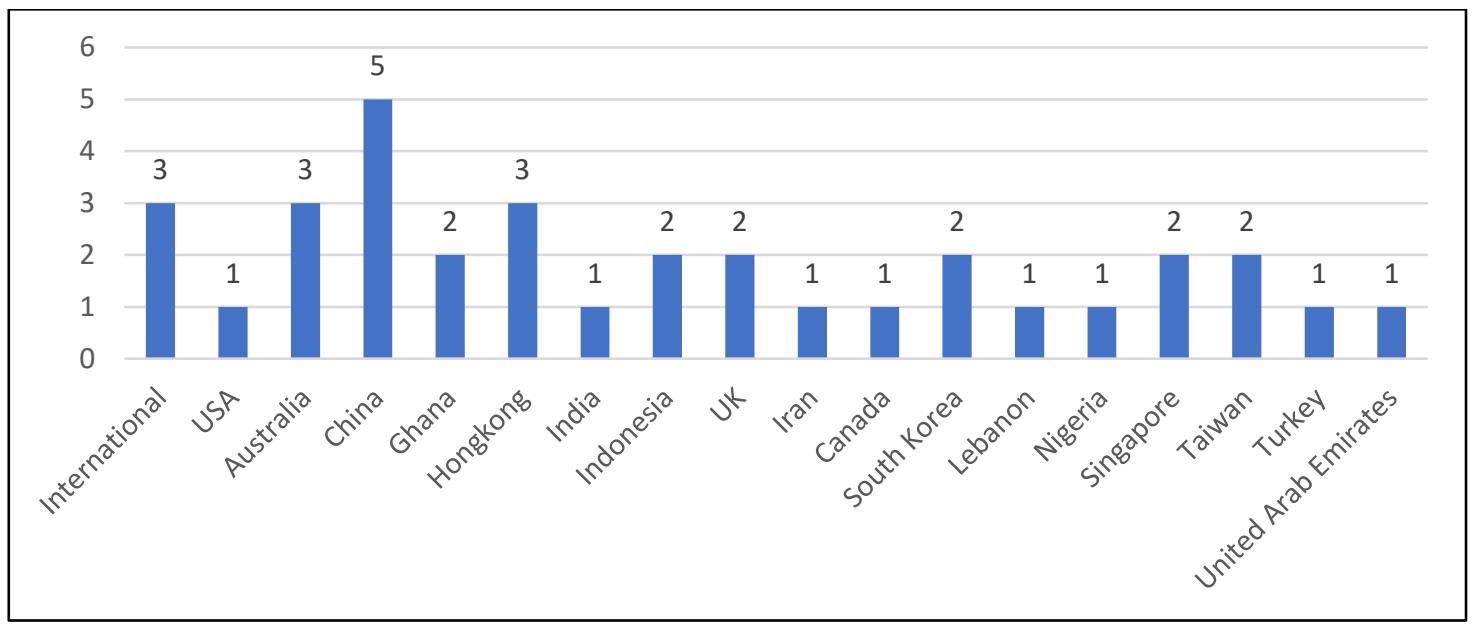

Figure 2. Countries as CSF research object on PPP Projects

China is the country with the PPP scheme that is the most widely used as the CSF research object. In China, PPP was firstly introduced to the Shajiao B power plant project in mid-1980. Since 1996, several projects began to be promoted with PPP under the Build-Operate-Transfer (BOT) scheme, such as the Laibin B power plant project and the Chengdu No. 6 water project. Since then, the private sector's involvement in infrastructure development in China has steadily increased (Ke et al., 2014). Research on CSF is necessary to understand better the factors that can determine PPP projects' success in China (Chan et al., 2010).

Based on Figure 2, Hong Kong ranks as the most studied country after China. The financial instability in Asia in the late 1990s had a significant impact on the Hong Kong government. With the various protests filed for better public service improvements due to Hong Kong's rapid development, alternative funding for the development is required, i.e., PPP. With the advantage that Hong Kong is the gateway to mainland China, foreign companies can enter the Asian market, where private contributions play a major role (Chan et al., 2007). Like China, PPP has increased in Hong Kong by exploring potential success factors for PPP projects (Cheung et al., 2012).

Australia occupies a position with the same score as Hong Kong (See Figure 2). PPP in Australia has been used to implement projects such as main toll roads, hospitals, prisons, schools, services, and sports facilities. Exploring PPP success factors in Australia includes case studies, such as the Sydney Super Dome and Australia Stadium, which have informed future practice practitioners for Australian PPP (Jefferies, 2006).

\section{Infrastructure sectors in CSF research}

PPPs have been used in various sectors to acquire several types of assets and facilities. Some countries merely focus on the use of PPP in specific sectors. This justification is intended to assist the government's investment priority policies, improve service performance, and prioritize areas where PPP is expected to be more successful (World Bank, 2017).

Table 1 presents the results of the search process for the infrastructure sector used in previous studies. As shown in Table 1, 15 articles applied the multi-sector concept to CSF research. It is assumed that the CSF identification results in the research can be applied to PPP projects in any sector. Five articles examined the success factors in the transportation infrastructure sector (Bae \& Joo, 2016; Chou et al., 2012; Babatunde \& Perera, 2017; Kulshreshtha et al., 2017; Min \& Jun 2014). Meanwhile, the other two articles examined the road infrastructure sector and sports facilities and infrastructure (Ahmadabadi \& Heravi, 2019; Wang, 2015; Jefferies et al., 2002; Jefferies, 2006). 
Table 1. Infrastructure sector in CSF research

\begin{tabular}{lcc}
\hline \multicolumn{1}{c}{ Infrastructure Sector } & Total article & $\%$ \\
\hline Drinking-Water Infrastructure & 1 & 3.6 \\
Sports Facilities and Infrastructure & 2 & 7.1 \\
Road Infrastructure & 2 & 7.1 \\
Housing Infrastructure & 1 & 3.6 \\
Water Resources and Irrigation Infrastructure & 1 & 3.6 \\
Telecommunication and Informatics Infrastructure & 1 & 3.6 \\
Transportation Infrastructure & 5 & 17.9 \\
Multi-sector & 15 & 53.6 \\
\hline \multicolumn{2}{c}{ Total } & 28 \\
\hline
\end{tabular}

Source: Processed data

\section{Identification of CSF findings on PPP Projects}

A summary of findings for identifying CSFs for each article is presented in Table 2. From 28 publications, the number of CSFs identified is 20 CSFs. The top five factors are appropriate risk allocation and sharing (identified in 19 articles), followed by a competitive and transparent procurement process, a favorable and efficient legal framework, and public and private sector commitments and responsibilities. Finally, a robust and reliable private consortium factor occupies the fifth position, discovered in 13 published articles.

Table 2. CSF findings on PPP Projects from 2000-2019

\begin{tabular}{|c|c|c|c|}
\hline No. & CSFs & Authors & Total \\
\hline 1 & $\begin{array}{l}\text { Appropriate risk } \\
\text { allocation and sharing }\end{array}$ & $\begin{array}{l}\text { Chou \& Pramudawardhani (2015); Hwang et al. (2013); Chou } \\
\text { et al. (2012); Wang (2015); Babatunde \& Perera (2017); Zhang } \\
\text { et al. (2012); Osei-Kyei \& Chan (2017); Jefferies (2006); Wang } \\
\text { et al. (2018); Jamali (2004); Osei-Kyei \& Chan (2017)a; Zhang } \\
\text { (2005); Gurgun \& Touran (2014); Tang et al. (2013); } \\
\text { Kumaraswamy \& Morris (2002); Abdel Aziz (2007); } \\
\text { Kulshreshtha et al. (2017); Min \& Jun (2014); Yang et al. } \\
\text { (2013) }\end{array}$ & 19 \\
\hline 2 & $\begin{array}{l}\text { Competitive and } \\
\text { transparent } \\
\text { procurement process }\end{array}$ & $\begin{array}{l}\text { Chou \& Pramudawardhani (2015); Hwang et al. (2013); Abdul- } \\
\text { Aziz \& Kassim (2011); Chou et al. (2012); Ng et al. (2012); } \\
\text { Babatunde \& Perera (2017); Wibowo \& Alfen (2014); Osei- } \\
\text { Kyei \& Chan (2017); Jefferies et al. (2002); Jefferies (2006); } \\
\text { Jamali (2004); Chan et al. (2010); Abdel Aziz (2007); Almarri } \\
\text { \& Boussabaine (2017); Kulshreshtha et al. (2017); Min \& Jun } \\
\text { (2014) }\end{array}$ & 16 \\
\hline 3 & $\begin{array}{l}\text { Favorable and } \\
\text { efficient legal } \\
\text { framework }\end{array}$ & $\begin{array}{l}\text { Chou \& Pramudawardhani (2015); Hwang et al. (2013); Chou } \\
\text { et al. (2012); Ng et al. (2012); Ameyaw \& Chan (2016); } \\
\text { Babatunde \& Perera (2017); Wibowo \& Alfen (2014); Zhang } \\
\text { et al. (2012); Wang et al. (2018); Jamali (2004); Osei-Kyei \& } \\
\text { Chan (2017)a; Gurgun \& Touran (2014); Kumaraswamy \& } \\
\text { Morris (2002); Abdel Aziz (2007); Kulshreshtha et al. (2017); } \\
\text { Yang et al. (2013) }\end{array}$ & 16 \\
\hline 4 & $\begin{array}{l}\text { Commitment and } \\
\text { responsibility of the } \\
\text { public and private } \\
\text { sectors }\end{array}$ & $\begin{array}{l}\text { Ahmadabadi \& Heravi (2019); Chou \& Pramudawardhani } \\
\text { (2015); Hwang et al. (2013); Abdul-Aziz \& Kassim (2011); } \\
\text { Chou et al. (2012); Ameyaw \& Chan (2016); Babatunde \& } \\
\text { Perera (2017); Zhang et al. (2012); Osei-Kyei \& Chan (2017); } \\
\text { Wang et al. (2018); Jamali (2004); Chan et al. (2010); Tang et } \\
\text { al. (2013); Almarri \& Boussabaine (2017); Kulshreshtha et al. } \\
\text { (2017); Min \& Jun (2014) }\end{array}$ & 16 \\
\hline 5 & $\begin{array}{l}\text { A robust and reliable } \\
\text { private consortium }\end{array}$ & $\begin{array}{l}\text { Ahmadabadi \& Heravi (2019); Chou \& Pramudawardhani } \\
\text { (2015); Hwang et al. (2013); ); Chou et al. (2012); Ng et al. } \\
\text { (2012); Wang (2015); Babatunde \& Perera (2017); Zhang et al. }\end{array}$ & 13 \\
\hline
\end{tabular}




\begin{tabular}{|c|c|c|c|}
\hline No. & CSFs & Authors & Total \\
\hline & & $\begin{array}{l}\text { (2012); Osei-Kyei \& Chan (2017); Jefferies et al. (2002); } \\
\text { Zhang (2005); Kumaraswamy \& Morris (2002); Kulshreshtha } \\
\text { et al. (2017) }\end{array}$ & \\
\hline 6 & $\begin{array}{l}\text { Stable } \\
\text { macroeconomic } \\
\text { conditions }\end{array}$ & $\begin{array}{l}\text { Ahmadabadi \& Heravi (2019); Chou \& Pramudawardhani } \\
\text { (2015); Chou et al. (2012); Ng et al. (2012); Zhang et al. (2012); } \\
\text { Osei-Kyei \& Chan (2017); Zhang (2005); Chan et al. (2010); } \\
\text { Gurgun \& Touran (2014); Kumaraswamy \& Morris (2002); } \\
\text { Almarri \& Boussabaine (2017); Kulshreshtha et al. (2017) }\end{array}$ & 12 \\
\hline 7 & $\begin{array}{l}\text { Legal, political and } \\
\text { social support }\end{array}$ & $\begin{array}{l}\text { Ahmadabadi \& Heravi (2019); Chou \& Pramudawardhani } \\
\text { (2015); Bae \& Joo (2016); Chou et al. (2012); Ng et al. (2012); } \\
\text { Ameyaw \& Chan (2016); Babatunde \& Perera (2017); Osei- } \\
\text { Kyei \& Chan (2017); Chan et al. (2010); Kumaraswamy \& } \\
\text { Morris (2002); Almarri \& Boussabaine (2017); Kulshreshtha et } \\
\text { al. (2017) }\end{array}$ & 12 \\
\hline 8 & Good governance & $\begin{array}{l}\text { Ahmadabadi \& Heravi (2019); Chou \& Pramudawardhani } \\
\text { (2015); Chou et al. (2012); Ng et al. (2012); Ameyaw \& Chan } \\
\text { (2016); Wibowo \& Alfen (2014); Wang et al. (2018); Chan et } \\
\text { al. (2010); Kulshreshtha et al. (2017); Yang et al. (2013) }\end{array}$ & 10 \\
\hline 9 & $\begin{array}{l}\text { Clear and precise } \\
\text { project identification } \\
\text { and summary }\end{array}$ & $\begin{array}{l}\text { Ahmadabadi \& Heravi (2019); Ameyaw \& Chan (2016); } \\
\text { Babatunde \& Perera (2017); Wibowo \& Alfen (2014); Osei- } \\
\text { Kyei \& Chan (2017); Jefferies (2006); Wang et al. (2018); Tang } \\
\text { et al. (2013); Kumaraswamy \& Morris (2002); Abdel Aziz } \\
\text { (2007) }\end{array}$ & 10 \\
\hline 10 & $\begin{array}{l}\text { Availability of } \\
\text { financial markets }\end{array}$ & $\begin{array}{l}\text { Ahmadabadi \& Heravi (2019); Chou \& Pramudawardhani } \\
\text { (2015); Bae \& Joo (2016); Chou et al. (2012); Babatunde \& } \\
\text { Perera (2017); Wibowo \& Alfen (2014); Zhang et al. (2012); } \\
\text { Kulshreshtha et al. (2017); Yang et al. (2013) }\end{array}$ & 9 \\
\hline 11 & $\begin{array}{l}\text { Government } \\
\text { involvement by } \\
\text { providing guarantees }\end{array}$ & $\begin{array}{l}\text { Ahmadabadi \& Heravi (2019); Chou \& Pramudawardhani } \\
\text { (2015); Chou et al. (2012); Babatunde \& Perera (2017); Osei- } \\
\text { Kyei \& Chan (2017); Almarri \& Boussabaine (2017); } \\
\text { Kulshreshtha et al. (2017); Yang et al. (2013) }\end{array}$ & 8 \\
\hline 12 & $\begin{array}{l}\text { Technical and } \\
\text { economic feasibility }\end{array}$ & $\begin{array}{l}\text { Ahmadabadi \& Heravi (2019); Chou \& Pramudawardhani } \\
\text { (2015); Abdul-Aziz \& Kassim (2011); Chou et al. (2012); } \\
\text { Wang (2015); Babatunde \& Perera (2017); Abdel Aziz (2007); }\end{array}$ & 7 \\
\hline 13 & $\begin{array}{l}\text { Financially attractive } \\
\text { projects and } \\
\text { profitable investments }\end{array}$ & $\begin{array}{l}\text { Wang (2015); Ameyaw \& Chan (2016); Wibowo \& Alfen } \\
\text { (2014); Wang et al. (2018); Tang et al. (2013); Kumaraswamy } \\
\text { \& Morris (2002); }\end{array}$ & 6 \\
\hline 14 & $\begin{array}{l}\text { Comprehensive and } \\
\text { realistic cost / benefit } \\
\text { assessment }\end{array}$ & $\begin{array}{l}\text { Chou \& Pramudawardhani (2015); Chou et al. (2012); } \\
\text { Babatunde \& Perera (2017); Jefferies et al. (2002); Yang et al. } \\
\text { (2013) }\end{array}$ & 5 \\
\hline 15 & $\begin{array}{l}\text { Clear goals and } \\
\text { objectives }\end{array}$ & $\begin{array}{l}\text { Chou \& Pramudawardhani (2015); Chou et al. (2012); Jamali } \\
\text { (2004); Tang et al. (2013); Min \& Jun (2014) }\end{array}$ & 5 \\
\hline 16 & $\begin{array}{l}\text { Efficient payment } \\
\text { mechanism }\end{array}$ & $\begin{array}{l}\text { Ng et al. (2012); Osei-Kyei \& Chan (2017); Wang et al. (2018); } \\
\text { Osei-Kyei \& Chan (2017)a; Kumaraswamy \& Morris (2002) }\end{array}$ & 5 \\
\hline 17 & $\begin{array}{l}\text { Appropriate } \\
\text { procedures and } \\
\text { arrangements for } \\
\text { contracts and } \\
\text { concession periods }\end{array}$ & $\begin{array}{l}\text { Ahmadabadi \& Heravi (2019); Chou \& Pramudawardhani } \\
\text { (2015); Wibowo \& Alfen (2014); Jefferies (2006); Abdel Aziz } \\
\text { (2007) }\end{array}$ & 5 \\
\hline 18 & $\begin{array}{l}\text { Safe, sound, and } \\
\text { secure economic } \\
\text { policy }\end{array}$ & $\begin{array}{l}\text { Chou \& Pramudawardhani (2015); Chou et al. (2012); Ng et al. } \\
\text { (2012); Wibowo \& Alfen (2014); }\end{array}$ & 4 \\
\hline 19 & $\begin{array}{l}\text { Well organized public } \\
\text { sector }\end{array}$ & $\begin{array}{l}\text { Chou \& Pramudawardhani (2015); Hwang et al.. (2013); Chou } \\
\text { et al.. (2012) }\end{array}$ & 3 \\
\hline 20 & $\begin{array}{l}\text { Technology transfer } \\
\text { and innovation }\end{array}$ & $\begin{array}{l}\text { Bae \& Joo (2016); Babatunde \& Perera (2017); Osei-Kyei \& } \\
\text { Chan (2017) }\end{array}$ & 3 \\
\hline
\end{tabular}

Table 2. indicates that irrespective of the project stage, infrastructure sector, or PPP project model, these factors are significant in supporting a PPP project's success. 
1. Appropriate risk allocation and sharing

Infrastructure development is a costly and complicated endeavor where project risks may arise if not handled properly. It is not surprising that a significant portion of identification was obtained through risk allocation and risk-sharing factors. Nineteen published articles from 2000 to 2019 considered this in the research.

Allocation and risk-sharing are one of the core components in the preparation of a PPP project. It is expected that a better CSF may result in better risk management through the process of clearly defining risks and allocating them to parties with more appropriate means of managing these risks, be it private or public (Osei-Kyei and Chan, 2015).

2. The competitive and transparent procurement process

A competitive and transparent procurement process ranks second out of the top five CSF rankings based on 16 articles.

A transparent and efficient procurement process is essential to reduce transaction costs and shorten negotiation and contract times. A clear description of the project and the required requirements may help achieve this during the tender process. In most cases, bidding alone cannot produce a robust private consortium that benefits the public (Chan, 2010).

3. Favorable and efficient legal framework

A total of 16 articles identified a favorable and efficient legal framework as an efficient factor in facilitating PPP projects' success. Sufficient legal resources must be available at a reasonable cost to maintain the legal structure and necessary documentation. A transparent and stable legal framework may assist in making contracts and agreements bankable. A proper dispute resolution system may help ensure the stability of the PPP contract. Governance rules, regulations, and appropriate reference manuals related to PPP have been well-established in several developed countries (such as the UK, Australia, Canada, and South Africa) to facilitate the potential adoption of the PPP procurement approach (Zhang et al., 2012).

4. Commitment and responsibility of the public and private sectors

Sixteen articles have identified the topic of commitment and responsibility of the public and private sectors. It is important to define and share the responsibilities of each party appropriately. It is important to create a strong relationship so that PPP can work smoothly as well. The attitude of stakeholders in PPP projects may affect the quality of project results. Therefore, the relationship and management among stakeholders must also be considered. For projects to be implemented, the public and private sectors must demonstrate an equal commitment to the PPP project's objectives (Chan, 2010; Almarri, 2017).

5. A robust and reliable private consortium

The final factor is a robust and reliable private consortium, identified in 13 articles from 28 published articles considered in this study.

Although the government is generally in a better position to create an enabling environment for private sector participation in public infrastructure development, the private sector plays a significant role in successfully implementing several PPP projects. The PPP project's complexity made it difficult for a construction company to complete the project, so many companies gathered to form a consortium. However, the structure and compatibility of these entities may affect the success of the project. A weak and poorly managed consortium created difficulties and ultimately caused PPP projects to fail. In this regard, the consortium must have strong technical, operational, and management skills to implement PPP projects (Osei-Kyei and Chan, 2015; Zhang, 2005). 


\section{CONCLUSIONS AND RECOMMENDATIONS}

\section{Conclusions}

It is noteworthy that while there were historically no publications in 2000 , there was an improvement and hit the most publications in 2017 with five publications by 28 papers from 2000 to 2019 included in this analysis. China became the most popular country studied in CSF research in the 2000-2019 period, followed by Hong Kong and Australia. There is little research in developing countries. The PPP concept has not received much development in those countries, or the documents used in this study are insufficient. Research for multi-sector infrastructure is ranked first as a sector considered in previous studies. It is expected so that CSF can be applied to any infrastructure sector in PPP projects to facilitate PPP implementation in the future. The transportation infrastructure sector is the next sector examined in the previous article, followed by the road infrastructure sector and the sports facilities infrastructure sector.

Five CSFs identified in 19 years of research considered appropriate risk allocation and sharing, competitive and transparent procurement process, favorable and efficient legal framework, commitment and responsibility of the public and private sectors, and the last one a robust and reliable private consortium.

The findings obtained in this study can provide an overview of CSFs for projects with PPP schemes in the future. The identified CSFs can also be applied to any PPP infrastructure sector and help stakeholders increase the likelihood of PPP project success and be adopted for further research.

\section{Recommendations}

The CSFs developed in this study can be used for further analysis or compare with other research results, and further research can expand the database used for more significant results.

\section{REFERENCES}

Abdel Aziz, A. M. (2007). Successful delivery of public-private partnerships for infrastructure development. Journal of construction engineering and management, 133(12), 918-931.

Abdul-Aziz, A. R., \& Kassim, P. J. (2011). Objectives, success and failure factors of housing public-private partnerships in Malaysia. Habitat International, 35(1), 150157.

Ahmadabadi, A. A., \& Heravi, G. (2019). The effect of critical success factors on project success in Public-Private Partnership projects: A case study of highway projects in Iran. Transport Policy, 73, 152-161.

Almarri, K., \& Boussabaine, H. (2017). The influence of critical success factors on value for money viability analysis in public-private partnership projects. Project management journal, 48(4), 93-106.

Ameyaw, E. E., \& Chan, A. P. (2016). Critical success factors for public-private partnership in water supply projects. Facilities, 34, 124-160.

Babatunde, S. O., \& Perera, S. (2017). Cross-sectional comparison of public-private partnerships in transport infrastructure development in Nigeria. Engineering, Construction and Architectural Management, 24, 875-900.

Bae, Y., \& Joo, Y. M. (2016). Pathways to meet critical success factors for local PPPs: The cases of urban transport infrastructure in Korean cities. Cities, 53, 35-42.

Chan, A. P., Lam, P. T., Chan, D. W., Cheung, E., \& Ke, Y. (2010). Critical success factors for PPPs in infrastructure developments: Chinese perspective. Journal of construction engineering and management, 136(5), 484-494. 
Chan, A. P., Lam, P. T., Chan, D. W., Cheung, E., Sidwell, T., \& Kajewski, S. (2007). A research framework for investigating public private partnerships $(P P P)$ in Hong Kong, Proceedings of the 4th International Conference on Construction in the 21st Century. Florida International University \& Griffith University, 334-341.

Chou, J. S., \& Pramudawardhani, D. (2015). Cross-country comparisons of key drivers, critical success factors and risk allocation for public-private partnership projects. International Journal of Project Management, 33(5), 1136-1150.

Chou, J. S., Tserng, H. P., Lin, C., \& Yeh, C. P. (2012). Critical factors and risk allocation for PPP policy: Comparison between HSR and general infrastructure projects. Transport Policy, 22, 36-48.

Grimsey, D., \& Lewis, M. K. (2002). Evaluating the risks of public private partnerships for infrastructure projects. International journal of project management, 20(2), 107-118.

Gurgun, A. P., \& Touran, A. (2014). Public-private partnership experience in the international arena: Case of Turkey. Journal of Management in Engineering, 30(6), 04014029.

Hwang, B. G., Zhao, X., \& Gay, M. J. S. (2013). Public private partnership projects in Singapore: Factors, critical risks and preferred risk allocation from the perspective of contractors. International journal of project management, 31(3), 424-433.

Jamali, D. (2004). Success and failure mechanisms of public private partnerships (PPPs) in developing countries. International Journal of Public Sector Management, 17(5), 414-430

Jefferies, M. (2006). Critical success factors of public private sector partnerships: : A Case Study of the Sydney SuperDome. Engineering, Construction and Architectural Management, 13(5), 451-462

Jefferies, M., Gameson, R. O. D., \& Rowlinson, S. (2002). Critical success factors of the BOOT procurement system: reflections from the Stadium Australia case study. Engineering Construction and Architectural Management, 9(4), 352-361.

Ke, Y., Jefferies, M., Shrestha, A., \& Jin, X. H. (2014). Public private partnership in China: where to from here. Organization, technology \& management in construction: an international journal, 6(3), 0-0

Ke, Y., Wang, S., Chan, A. P., \& Cheung, E. (2009). Research trend of public-private partnership in construction journals. Journal of construction engineering and management, 135(10), 1076-1086.

Kulshreshtha, R., Kumar, A., Tripathi, A., \& Likhi, D. K. (2017). Critical success factors in implementation of urban metro system on PPP: A case study of hyderabad metro. Global Journal of Flexible Systems Management, 18(4), 303-320.

Kumaraswamy, M. M., \& Morris, D. A. (2002). Build-operate-transfer-type procurement in Asian megaprojects. Journal of construction Engineering and Management, 128(2), 93-102.

Li, B., Akintoye, A., Edwards, P. J., \& Hardcastle, C. (2005). Critical success factors for $\mathrm{PPP} / \mathrm{PFI}$ projects in the UK construction industry. Construction management and economics, 23(5), 459-471.

Liu, T., \& Wilkinson, S. (2011). Adopting innovative procurement techniques: obstacles and drivers for adopting public private partnerships in New Zealand. Construction Innovation, 11(4), 452-469.

Min, H., \& Jun, C. Y. (2014). Public-private partnerships for the development of port hinterlands and their ramifications for global supply chain management. Maritime Economics \& Logistics, 16(3), 250-275.

Ng, S. T., Wong, Y. M., \& Wong, J. M. (2012). Factors influencing the success of PPP 
at feasibility stage-A tripartite comparison study in Hong Kong. Habitat international, 36(4), 423-432.

Osei-Kyei, R., \& Chan, A. P. (2017). Empirical comparison of critical success factors for public-private partnerships in developing and developed countries. Engineering, Construction and Architectural Management, 24(6), 1222-1245.

Osei-Kyei, R., \& Chan, A. P. (2017)a. Perceptions of stakeholders on the critical success factors for operational management of public-private partnership projects. Facilities, 35(1/2), 21-38.

World Bank. (2017). Public-private partnerships: reference guide version 3.0.

Rockart, J. F. (1980). The changing role of the information systems executive: a critical success factors perspective, Working papers 1297-82, Report (Alfred P, Massachusetts Institute of Technology (MIT), Sloan School of Management.

Tang, L., Shen, Q., Skitmore, M., \& Cheng, E. W. (2013). Ranked critical factors in PPP briefings. Journal of management in engineering, 29(2), 164-171.

Wang, L., Zhang, P., Zhang, P., Li, R., Zhang, Y., \& Wu, Y. (2018). A systematic approach for public-private partnership projects CSFs evaluation. Engineering, Construction and Architectural Management, 25(9), 1127-1145.

Wang, Y. (2015). Evolution of public-private partnership models in American toll road development: Learning based on public institutions' risk management. International Journal of Project Management, 33(3), 684-696.

Wibowo, A., \& Alfen, H. W. (2014). Identifying macro-environmental critical success factors and key areas for improvement to promote public-private partnerships in infrastructure. Engineering, Construction and Architectural Management, 21(4), 383-402.

Yang, Y., Hou, Y., \& Wang, Y. (2013). On the development of public-private partnerships in transitional economies: An explanatory framework. Public administration review, 73(2), 301-310.

Zhang, X. (2005). Critical success factors for public-private partnerships in infrastructure development. Journal of construction engineering and management, 131(1), 3-14.

Zhang, X., Cheung, E., Chan, A. P., Lam, P. T., Chan, D. W., \& Ke, Y. (2012). A comparative study of critical success factors for public private partnerships (PPP) between Mainland China and the Hong Kong Special Administrative Region. Facilities, 30(13/14), 647-666. 